\title{
Diffuse knapweed and bluebunch wheatgrass seedling growth under stress
}

\author{
G. KIEMNEC, L. L. LARSON, AND A. GRAMMON
}

Authors are Associate Professor, Department of Crop and Soil Science, professor, Department of Rangeland Resources, and Weed Control Supervisor, Baker County, Oregon, Oregon State University, Corvallis, Ore. 97331.

\begin{abstract}
Growth characteristics of diffuse knapweed (Centaurea diffusa Lam.) and bluebunch wheatgrass (Pseudoroegneria spicata (Pursch) Scribn. \& Smith) seedlings were evaluated in 2 temperature regimes, 10 and $16^{\circ} \mathrm{C}$, and 2 moisture regimes, - 0.01 and $0.03 \mathrm{MPa}$, in an environmental chamber. In cool, wet conditions, root penetration was greater for diffuse knapweed roots than bluebunch wheatgrass roots, but penetration was equal in warm, dry conditions. Root lengths for both species were equal in cool, wet conditions; but, bluebunch wheatgrass root length was greater in warm, dry conditions. Leaf area of diffuse knapweed was greater than bluebunch wheatgrass in warm, dry conditions. Drier, but not cooler, conditions favored diffuse knapweed leaf area over bluebunch wheatgrass leaf area. Root:shoot ratios for bluebunch wheatgrass were greater than diffuse knapweed in all environmental conditions. Results suggest that bluebunch wheatgrass should be more competitive than diffuse knapweed for nutrients and water at lower depths in warmer, drier conditions. Diffuse knapweed should be more competitive for nutrients and water in wetter conditions.
\end{abstract}

Key Words: Noxious weeds, Centaurea diffusa, Pseudoroegneria spicata, seedling growth, water, temperature

Bluebunch wheatgrass (Pseudoroegneria spicata (Pursh) Scribn. \& Smith) is a common native perennial grass of western North America that has been developed as a commercial seed source through the varieties 'Whitmar', and 'Goldar'. Seedling establishment is the first step for natural plant spread or seeding efforts in range environments. Successful bluebunch seedling establishment is a function of root penetration (Nelson et al. 1970), soil temperature (Miller et al. 1986), and soil water content (Johnson and Aguirre 1991). Early root development and penetration are essential for bluebunch wheatgrass establishment (Johnson and Aguirre 1991, Hassenyar and Wilson 1978). Root branching of bluebunch wheatgrass is decreased by a reduction in soil water availability (Johnson and Aguirre 1991).

Invasive weeds have the ability to reduce the productive capacity of native grasslands (Olsen 1999). Annual weeds may have an advantage in competition with bluebunch seedlings through faster root growth and soil penetration. Cheatgrass (Bromus tectorum L.) has demonstrated greater root and leaf growth than 'Whitmar' bluebunch wheatgrass (Harris 1967).

Manuscript accepted 17 Apr. 02

\section{Resumen}

Se evaluaron las características de crecimiento de plántulas de "Diffuse knapweed" (Centaurea diffusa Lam.) y "Bluebunch wheatgrass" (Pseudoroegneria spicata (Pursch) Scribn. \& Smith) en dos regímenes de temperatura 10 y $16^{\circ} \mathrm{C}$ y 2 de humedad, 0.01 y -0.03 MPa, para lo cual se uso una camara ambiental. En condiciones frías y húmedas la penetración de raíz fue mayor para "Diffuse knapweed" que para "Bluebunch wheatgrass, pero la penetración fue igual en condiciones calientes y secas. La longitud de raíz de ambas especies fue igual en condiciones frías y húmedas, pero la longitud de raíz del "Bluebunch wheatgrass" fue mayor en condiciones calientes y secas. En condiciones calientes y secas, el área foliar de "Diffuse knapweed" fue mayor que la de"Bluebunch wheatgrass". Condiciones secas, pero no frías, favorecieron el área foliar de "Diffuse knapweed" sobre el área foliar del "Bluebunch wheatgrass". En todas las condiciones ambientales evaluadas la relación tallo:hoja del "Bluebunch wheatgrass" fue mayor que la del "Diffuse knapweed". Los resultados siguieren que el "Bluebunch wheatgrass"debe ser mas competitivo que el "Diffuse knapweed" por nutrientes y agua a bajas profundidades en condiciones secas y calientes. "Diffuse knapweed"debe ser mas competitivo por nutrientes y agua en condiciones húmedas.

Invading noxious weed species such as diffuse knapweed (Centaurea diffusa Lam.) are most likely to pose a competitive problem in bitterbrush (Purshia tridentata (Pursh) DC.)/bluebunch wheatgrass community types (Talbott 1987). The density of diffuse knapweed has been suggested as an indicator of range degradation (Roche and Roche 1999). Diffuse knapweed exists in a wide variety of environments (Roche and Roche 1991) and exhibits life cycles ranging from annual to triennial (Thompson and Stout 1991). Seed production from plants with this range of environmental plasticity is variable (Schirman 1981).

Seedling establishment is a critical phase of knapweed invasion. Studies have shown water stress increases knapweed seedling mortality in field plots (Berube and Myers 1982). Other studies suggest that competitive grass seedlings can initiate water stress (Larson and McInnis 1989, Huston et al. 1984).

Understanding the growth response of seedlings in varying environmental conditions can help explain establishment success and invasion potential of weedy species. The objective of this study was to compare seedling growth responses of diffuse knapweed and bluebunch wheatgrass combinations to varying regimens of water and temperature. 


\section{Methods and Materials}

Mature diffuse knapweed plants were collected near LaGrande, Ore. $\left(45^{\circ} 18^{\prime} \mathrm{N}\right.$, $118^{\circ} 04^{\prime} \mathrm{W}$ )and stored for 3 months in plastic grain sacks at $22^{\circ} \mathrm{C}$ before seed heads were removed. After shattering the seed heads, seeds were cleaned in a mechanical seed cleaner and shriveled seed discarded. Foundation 'Goldar' bluebunch wheatgrass was obtained from Grassland West (Culde-sac, Ida.). Seeds of both species were rinsed with $5 \%$ sodium hypochlorite solution for 30 seconds followed by 3 distilled water rinses $(15 \mathrm{ml})$.

Diffuse knapweed and 'Goldar' bluebunch wheatgrass were grown for 30 days in an environmental chamber in 4 temperature/water regimes: $10^{\circ} \mathrm{C}$ and $-0.01 \mathrm{MPa}$ (cool/wet), $16^{\circ} \mathrm{C}$ and $-0.01 \mathrm{MPa}$ (hot/wet), $10^{\circ} \mathrm{C}$ and $-0.03 \mathrm{MPa}$ (cool/dry), and $16^{\circ} \mathrm{C}$ and $-0.03 \mathrm{MPa}$ (hot/dry). Individual plants of each species were established in vertically split, taped polyvinyl chloride tubes $(80 \mathrm{~cm}$ in height $\mathrm{X}$ $81 \mathrm{~cm}^{2}$ cross section area) filled with a Walla Walla silt loam (coarse-silty, mixed, mesic Typic Haploxeroll). Soil water levels were attained by batch-mixing soil with water until a tensiometer reading was constant at $-0.01 \mathrm{MPa}$ or $-0.03 \mathrm{MPa}$. As soil was added to the tubes, they were tapped on concrete to facilitate soil settling. Tubes were arranged in a randomized-completeblock design in an environmental chamber $\left(10^{\circ} \mathrm{C}\right.$ or $16^{\circ} \mathrm{C}, 12$ hours daylength, 500 $\mathrm{uEm}^{-2} \mathrm{sec}^{-1}$ spectral light), with blocks as locations within the chamber.

Harvest occurred at 10,20, and 30 days after emergence. At harvest, tubes were split, soil washed away, and root depth penetration measured. Roots were separated from shoots, and total root length was measured using a root length scanner (CI203RL, CID, Inc., Vancouver, Wash.). Leaf area was measured using the same instrument. Leaves and roots were dried at $60^{\circ} \mathrm{C}$ for 48 hours and weighed. Growth data were analyzed in a $2 \times 2 \times 2$ factorial using ANOVA with mean differences separated using Fisher's protected LSD test $(\mathrm{P}=0.05)$.

\section{Results and Discussion}

Growth at 10 and 20 days was not significantly different among treatments. The results reported are for 30 days of growth. Interactions between water and temperature were not significant, therefore only species by water and species by temperature interactions will be discussed.

Table 1. Means and standard errors for growth parameters of diffuse knapweed and bluebunch wheatgrass as influenced by soil water regimes.

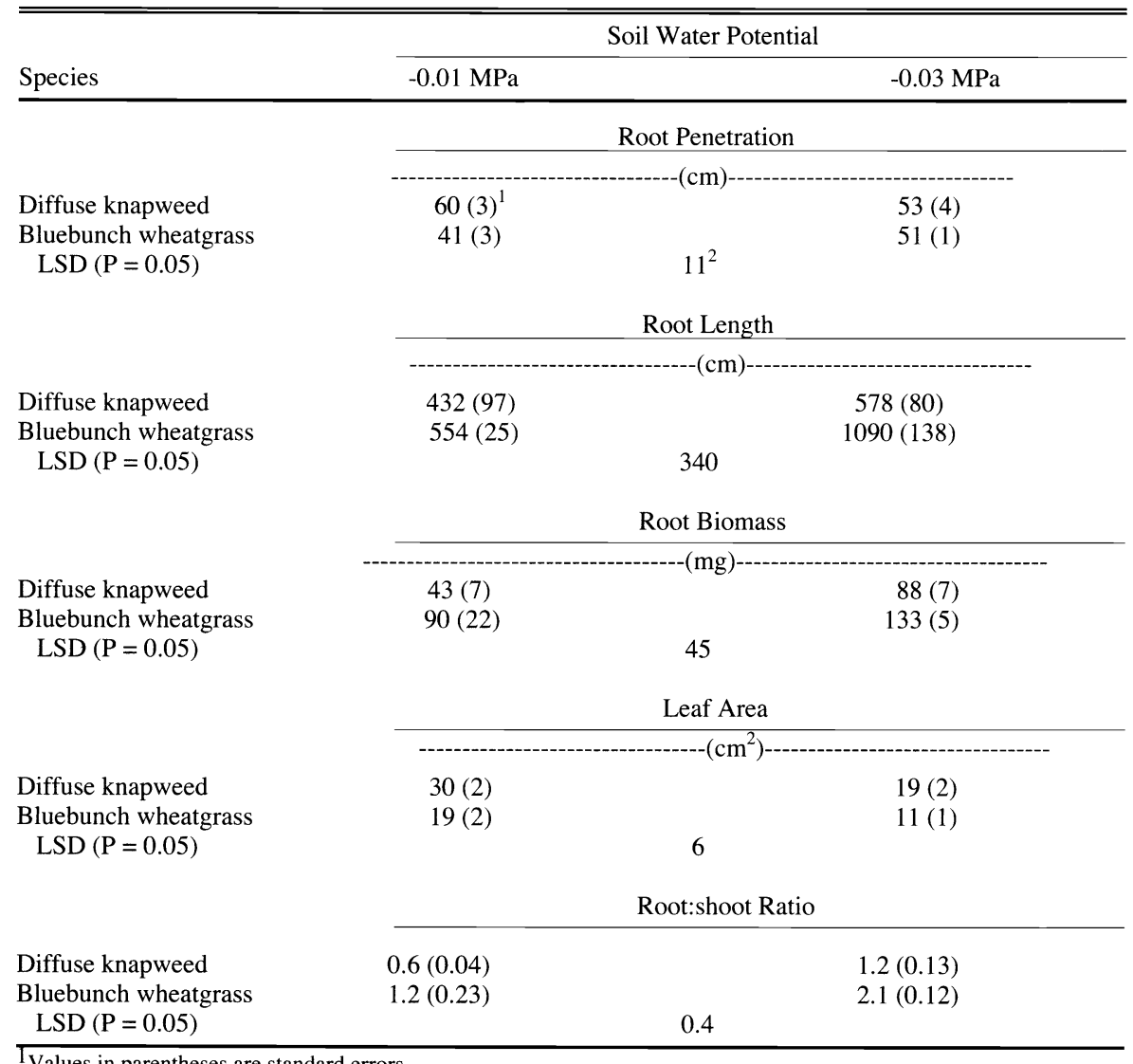

Values in parentheses are standard errors.

${ }^{2}$ LSD for comparisons between species or water potentials.

Roots of diffuse knapweed penetrated soil deeper than roots of bluebunch wheatgrass at $-0.01 \mathrm{MPa}$, but not at $-0.03 \mathrm{MPa}$ (Table 1). Greater penetration of diffuse knapweed roots was also evident at $10^{\circ} \mathrm{C}$ (Table 2). Rooting depth of both species increased at $16^{\circ} \mathrm{C}$ compared to $10^{\circ} \mathrm{C}$, with depths being equal between species at $16^{\circ} \mathrm{C}$.

Root lengths of species were equal at $-0.01 \mathrm{MPa}$ (Table 1). Length of bluebunch wheatgrass roots was increased with increased water stress, whereas, length of diffuse knapweed roots was not. Root biomass of both species increased with water stress. Apparently diffuse knapweed produced thicker roots than bluebunch wheatgrass with the water stress encountered in our experiment. Secondary root growth of dicotyledonous plants may account for this difference in root morphology between diffuse knapweed and bluebunch wheatgrass. Bluebunch wheatgrass produced greater root biomass than diffuse knapweed in both moisture regimes. Root lengths and biomass were equal between species at $10^{\circ} \mathrm{C}$, but both were greater for bluebunch wheatgrass than for knapweed at $16^{\circ} \mathrm{C}$ (Table 2). Additional root length at warmer soil temperatures would favor increased nutrient uptake by bluebunch wheatgrass over diffuse knapweed.

Leaf area for each species was reduced by increased water stress (Table 1), and increased by a warmer temperature (Table 2). Leaf area of diffuse knapweed was greater than bluebunch wheatgrass at each water regime. Diffuse knapweed leaf area increased about 20 -fold when grown in $16^{\circ} \mathrm{C}$ as compared to $10^{\circ} \mathrm{C}$, while bluebunch wheatgrass leaf area increased about 10 -fold.

The root:shoot ratio of bluebunch wheatgrass was greater than diffuse knapweed in all environmental regimes; root:shoot ratios increased for both species with higher water stress (Table 1). Each species put more resources into root growth and less into leaf production at $-0.03 \mathrm{MPa}$ compared to $-0.01 \mathrm{MPa}$. The root:shoot ratio for bluebunch wheatgrass decreased with increasing temperature (Table 2). These findings agree with those of Klepper (1991) that higher root:shoot 
Table 2. Means and standard errors for growth parameters of diffuse knapweed and bluebunch wheatgrass as influenced by temperature regimes.

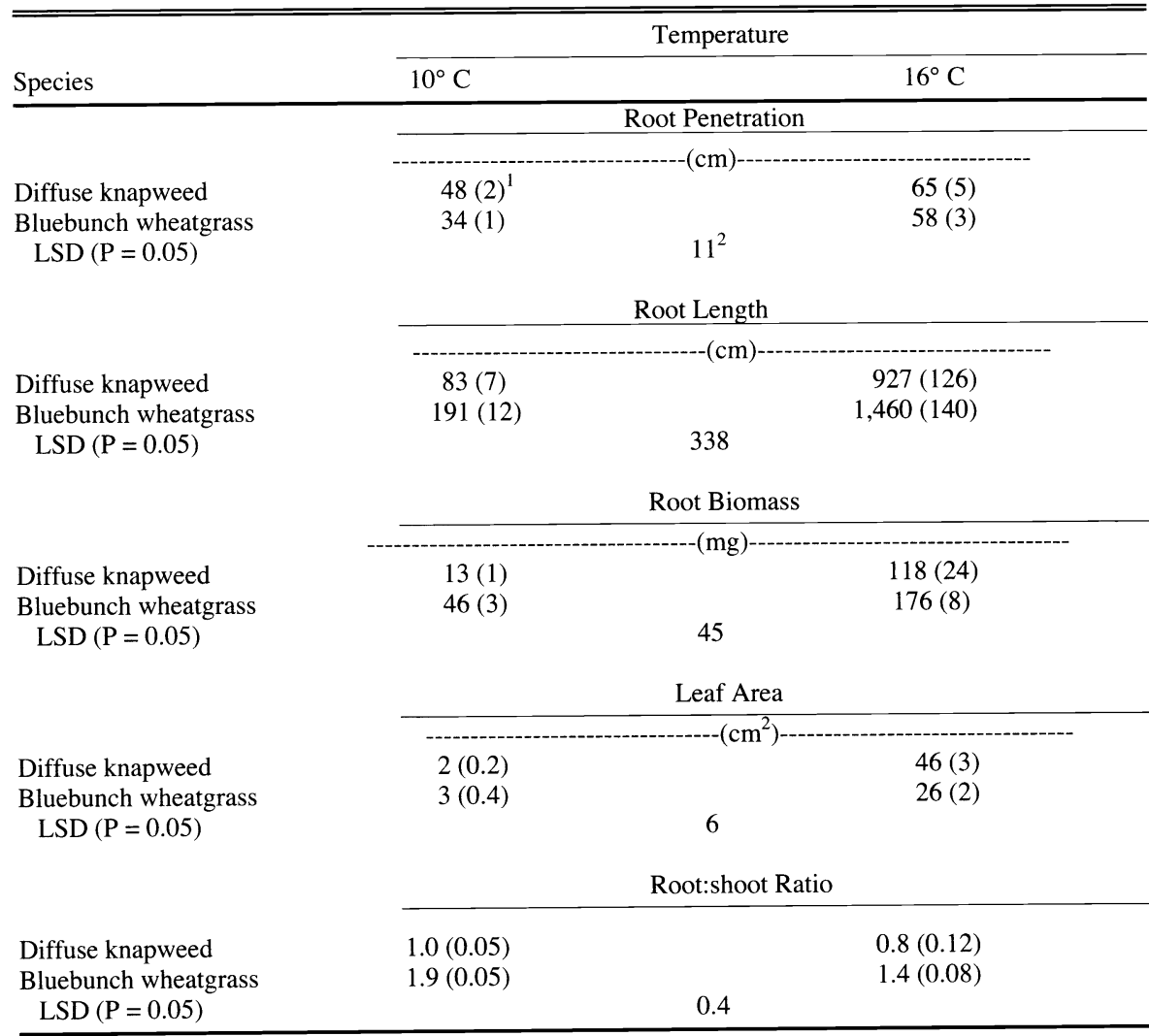

Values in parentheses are standard errors.

${ }^{2}$ LSD for comparisons between species or temperature.

ratios are generally found in stressed compared to non-stressed plants.

Rooting characteristics influence the competitive effectiveness of range plants (Johnson and Aguirre 1991). In many situations resource preemption is determined primarily by rapid germination and root growth (Harper 1977). Results from this study suggest diffuse knapweed derives a root penetration advantage over bluebunch wheatgrass in cool, moist conditions but not in warm, dry conditions. Bluebunch wheatgrass seedlings grew numerous adventitious roots in the $0-10 \mathrm{~cm}$ soil depth in moist conditions, while a singular seminal root extended into the deeper soil depths in dry conditions. This apparent transition in root morphology resulted in greater root length for bluebunch wheatgrass compared to diffuse knapweed in drier conditions. Plummer (1943) suggested that root length of bluebunch wheatgrass may play a role in its competitive ability in the seedling stage. These results appear to support conclusions by Berube and Myers (1982) and Sheley et al. (1997) that diffuse knapweed establishment is enhanced with above normal precipitation in spring (i.e., cool and moist conditions).
Poorter and Remkes (1990) indicate that faster growing species, given ideal conditions, tend to maximize shoot function while slower growing species generally maximize root function. Leaf area data and root:shoot ratios suggest that diffuse knapweed is the faster growing species in comparison to bluebunch wheatgrass.

We speculate that a shift to a warmer, drier climate would result in bluebunch wheatgrass being more competitive for nutrients and water at deeper soil depths $(>50 \mathrm{~cm})$. However, in wetter conditions, with deeper root penetration and similar root lengths, diffuse knapweed would be more competitive than bluebunch wheatgrass for water and nutrients.

\section{Literature Cited}

Berube, D.E. and J.H. Myers. 1982. Suppression of knapweed invasion by crested wheatgrass in the dry interior in British Columbia. J. Range Manage. 35:459-461.

Harper, J. L. 1977. The population biology of plants. Academic Press, London, U.K.
Harris, G.A. 1967. Some competitive relationships between Agropyron spicatum and Bromus tectorum. Ecol. Monogr. 37:89-111.

Hassenyar, A.S. and A.M. Wilson. 1978. Drought tolerance of seminal lateral root apices in crested wheatgrass and Russian wildrye. J. Range Manage. 31: 254-258.

Huston, C.H., R.H. Callihan, and R.L. Sheley. 1984. Reseeding intermediate wheatgrass in yellow starthistle-infested rangeland. Univ. of Idaho Ext. Curr. Information Ser. No. 634:42-44.

Johnson, D.A. and L. Aguirre. 1991. Effect of water on morphological development in seedlings of three range grasses: Root branching patterns. J. Range Manage. 44:355-360.

Klepper, B. 1991. Root-shoot relationships, p.265-286. In: Y. Waisel, A. Eshel, and U. Kafkafi (eds.). Plant roots. Marcel Dekker, Inc., New York.

Larson, L.L. and M.L. McInnis. 1989. Impact of grass seedlings on establishment and density of diffuse knapweed and yellow starthistle. Northw. Sci. 63:162-166.

Miller, R.F., J.M. Seufert, and M.R. Haferkamp. 1986. The ecology and management of bluebunch wheatgrass (Agropyron spicatum): A review. Oregon State Agr. Exp. Sta. Bull. 669. Corvallis, Ore.

Nelson, J.A., A.M. Wilson, and C.J. Goebel. 1970. Factors influencing broadcast seeding in bunchgrass range. J. Range Manage. 23:163-170.

Olsen, B. E. 1999. Impacts of noxious weeds on ecologic and economic systems, p. 4-18. In: R.J. Sheley and J.K. Petroff (eds.). Biology and management of noxious rangeland weeds Oregon State University Press, Corvallis, Ore.

Plummer, A.P. 1943. The germination and early seedling development of twelve range grasses. Amer. Soc. Agron. J. 35:19-34.

Poorter, H. and C. Remkes. 1990. Leaf area ratio and net assimilation rate of 24 wild species differing in relative growth rate. Oecol. 83:553-559.

Roche, B. F. and C.T. Roche. 1991. Identification, introduction, distribution, ecology and economics of Centaurea species, p. 274-291. In: L.F. James, J.O. Evans, M.H Ralphs, and R.D. Childs (eds.). Noxious range weeds. Westview Press, Boulder, Colo.

Roche, Jr., B. F. and C.T. Roche. 1999. Diffuse knapweed, p. 217-230. In: R.J. Sheley and J.K. Petroff (eds.). Biology and management of noxious rangeland weeds. Oregon State University Press, Corvallis, Ore.

Schirman, R. 1981. Seed production and spring establishment of diffuse and spotted knapweed. J. Range Manage. 37:501-502.

Sheley, R.L., B.E. Olson, and L.L. Larson. 1997. Effect of weed seed rate and grass defoliation level on diffuse knapweed. J. Range Manage. 25:364-367.

Talbott, C.J. 1987. Distribution and ecological amplitude of selected Centaurea species in Eastern Washington. M.S. Thesis. Washington State University, Pullman, Wash

Thompson, D.J. and D.G. Stout. 1991. Duration of the juvenile period in diffuse knapweed (Centaurea diffusa). Can. J. Bot. 69:368-371. 